\title{
DRAWING THE S(ELF): EXPLORING INDIVIDUAL REPERTORIES THROUGH AUTOBIOGRAPHICAL ILLUSTRATIONS WITHIN THE ENGLISH AS A LINGUA FRANCA PERSPECTIVE
}

\author{
Drawing the s(ELF): Explorando repertórios individuais por \\ meio de ilustrações autobiográficas dentro da perspectiva Inglês \\ como Língua Franca
}

\author{
João Victor SCHMICHECK \\ Universidade Federal do Paraná \\ victorschmicheck@gmail.com \\ https://orcid.org/0000-0001-7402-8485 \\ Amanda Belardo da SILVA \\ Universidade Federal do Paraná \\ amanda.belardo@gmail.com \\ https://orcid.org/0000-0003-0184-4128
}

\begin{abstract}
Current research on English teaching has increasingly turned to the notion of English as a Lingua Franca (ELF). However, when we look at the reality of the classroom, teachers still feel insecure about how to employ this concept and the discussions throughout their practice and the research ends up, largely, in the academic scope. Therefore, in this study we explore discussions and reflections of students about their experiences with English learning through an activity involving autobiographical illustrations. To this end, throughout the text we approach the elements that constitute ELF - to the detriment of the concept of English as a Foreign Language; we present studies that approach ELF within the classroom; we describe our methodology, the activity we propose with students, and discuss the results based on the issues raised. From this, we argue that activities like the one proposed here can be used by teachers to understand the individual repertoires of their students and, with that, to raise possible ways to work in the classroom having the ELF paradigm as its basis. We finish, then, with some possibilities of approaches focusing the development of an ELF-informed classroom practice. KEYWORDS: English as a Lingua Franca; Visual methods; Autobiographies.
\end{abstract}

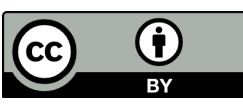


RESUMO: Pesquisas atuais sobre o ensino de inglês têm se voltado cada vez mais para a noção de Inglês como Língua Franca (ILF). Todavia, quando olhamos para a realidade de sala de aula, professores ainda se sentem inseguros sobre como empregar essa concepção ao longo de sua prática e as pesquisas às vezes acabam ficando no âmbito acadêmico. Sendo assim, neste trabalho exploramos discussões e reflexões de alunos sobre suas experiências com o aprendizado de inglês por meio de uma atividade envolvendo ilustrações autobiográficas. Para isso, ao longo do texto abordamos os elementos que constituem o ILF - em detrimento da concepção de Inglês como Língua Estrangeira (ILE); apresentamos alguns trabalhos que buscam relacionar o ILF e a sala de aula; descrevemos nossa metodologia de estudo e a atividade que propomos com os alunos e discutimos seus resultados com base nas problematizações levantadas. A partir disso, defendemos que atividades como a proposta aqui podem ser um meio de entender os repertórios individuais desses alunos e, com isso, de levantar caminhos possíveis para serem tomados no trabalho em sala de aula tendo o paradigma ILF como sua base. Finalizamos, então, com algumas possibilidades de abordagens com enfoque no desenvolvimento de uma prática de sala de aula informada pelo ILF. PALAVRAS-CHAVE: Inglês como língua franca; Métodos visuais; Autobiografias.

\section{INTRODUCTION}

As teachers-working in the most varied contexts of teaching and learning languages - when we ask students "why are you learning English?" the answers almost always come with phrases like "because it is very important for my future". Whether they are thinking about a professional or academic career, or being influenced by outside motivations and incentives on the part of the family and the school, this value of importance in relation to the English language is quite evident among students' and institutions' discourses. Also very common are the surprised reactions and confused looks when we ask English students to try and go a little further in their answers: but what is so important about English when it comes to your future? Usually they are not able to formulate an answer for this question, although they strongly believe that knowing English will provide them with good opportunities, be it professionally or personally.

These discourses seem to spread like wildfire in the current globalized world. According to Jenkins, Cogo and Dewey (2011, p. 303), "globalization is the process by which the world has become/is becoming more interconnected, where relations across local, regional and global contexts become more enmeshed, where flows of language, culture and people are intensified and accelerated.". In this sense, a hegemony of English 
can be perceived, specially in the field of language teaching and learning, as it ends up being preferred over other languages (MELO-PFEIFER, 2018). Thus, in a world characterized by its interconnections between different contexts, cultures and languages, the idea that English opens doors to whoever speaks it is widespread and this language is still seen as the international language.

Considering these issues, another widely disseminated notion is that of English as the language of the other, i.e., as a foreign language. This happens because the terminology English as a Foreign Language (EFL), historically used to refer to the teaching and learning of English, implies a way of conceptualizing the language as an entity external to the subject who learns it outside of a native context (JORDÃO, 2014). Moreover, the term comes from a modern concept of language, whose orientation is monolingual and "conditions us to conceive languages as closed systems, belonging to certain peoples or countries, considering the mixture between them as something negative" (GALOR; HAUS, 2019, p. 255²).

However, this is not the reality that teachers encounter when entering the classroom. Most students do not learn English only with/from native speakers or through experiences abroad. On the contrary, contact with the English language occurs through activities carried out in their local context. These, in turn, can be related to the formal learning in school or English courses, in which these learners communicate with teachers and classmates who, like them, are non-native English speakers. There are also students who report a more self-taught experience, in which learning takes place through specific and significant materials and experiences unique for each individual.

In addition, among the students' established objectives, travelling to Englishspeaking countries loses space for other types of investments in English learning. Many students want to be able to consume, more autonomously, products for entertainment, work or study available in English, without the need of translation. Other times, students learn the language in order to have an academic career, considering the requirements of graduate programs for activities that focus on internationalization which, in large part, take place through English language production. These are just two of the many scenarios encountered by English teachers in classrooms today.

In this sense, although some teaching contexts continue to be haunted by traditional elements that usually correspond to the notion of English as a Foreign Language (EFL),

\footnotetext{
${ }^{1}$ In the original: "nos condiciona a conceber as linguas como sistemas fechados, pertencentes a determinados povos ou países, considerando a mistura entre elas como algo negativo." (GALOR; HAUS, 2019, p. 255).
} 
it is possible to say that English is not external or foreign to some students. On the contrary, the relationships being established by non-native speakers with English seem to increasingly turn to the notion of English as a Lingua Franca (ELF). From this perspective, the focus is no longer on the different varieties of English - e.g., native/non-native - but on the role it plays in multilingual contexts in which non-native speakers can also be seen as agents and English is no longer seen as the "language of the other".

The ELF perspective has several pedagogical implications, demanding that teachers rethink their practices. In academic conferences, when we discuss the concept of ELF, several teachers seem to have one common question: how can we bring the notion of ELF into the classroom? The answer, however, is not simple. One of the aspects that research on pedagogies of English from an ELF perspective point out is that studies on the local and individual realities of each context are extremely important for the effective dissemination of this way of understanding the language (JENKINS; COGO; DEWEY, 2011). Therefore, a universal teaching formula based on ELF is not possible. Each local reality raises the need for a different kind of approach, weighing in its students, their relationship with English, objectives and investments in learning, among other factors.

Considering, then, the locality aspect, we believe that there are some paths that may be viable options for several teachers who would like to start adopting an ELFinformed pedagogical practice. Thus, we address the idea of exploring students and their unique repertoires as a possibility to develop classes based on ELF concepts and developments. We performed this through a first class activity, where a moment of exchange of learning experiences between students was proposed. We hypothesized that the use of the visual method can be a fruitful possibility for teachers to get to know their students, their realities, repertories, objectives, and, as a result, to elaborate plans based on the specific demands of each context.

Thus, we used a drawing activity based on the study by Melo-Pfeifer and Schmidt (2014) to promote a discussion about the English learning experiences of students at Celin UFPR, a Language Center located in Curitiba, Brazil. From this, we sought to understand their repertoires (the way they have learned English and how they relate to the language in their individual realities) and also to raise some possible paths, guided by an ELF perspective, that can be taken in the classroom.

In the next section, we discuss the main differences between English as a Foreign Language and English as a Lingua Franca, and highlight the language concept we assume in this study. Then, we discuss studies that already dealt with English teaching centered on an ELF perspective. The fourth section of the text addresses the methodology used 
for the production and analysis of autobiographical illustrations, while the fifth brings the discussion on the material presented. In the final section, we weave possible ideas for activities and classroom attitudes elicited from the discussion presented.

\section{EFL OR ELF: WHAT IS THE DIFFERENCE?}

As we mentioned earlier, we often find contrasting elements and ways of understanding the English language operating together in the same teaching and learning contexts. In this study, we work with the reality of Celin UFPR, a language center affiliated to the Federal University of Paraná (UFPR). Students, mostly undergraduate and graduate, usually arrive in the classrooms having had previous contact with the English language in their daily lives. However, they take a course that, although open for experimentation and for different activities, is supported mainly by the use of textbook materials that do not reflect their specific realities, and that adopt the native varieties of English considered prestigious and seen as those that must be followed and assimilated. Therefore, despite being an open space where teachers are free to explore different approaches in the teaching of foreign languages, the concept of the dominant variety as the model to be followed still prevails.

If we take into account the context that we are describing and follow a discussion such as the one proposed by Jenkins, Cogo and Dewey (2011), it can be said that, on the one hand, there is the perspective of English as a Foreign Language (EFL), which is "part of the MODERN (FOREIGN) LANGUAGES paradigm, according to which most interaction involving non-native speakers is with native speakers of the language, and non-native speakers' goal is to approximate the native variety as closely as possible." (JENKINS; COGO; DEWEY, 2011, p. 284, emphasis in the original). On the other, there is the vision of English as a lingua franca (ELF) that started as "part of the GLOBAL ENGLISHES paradigm, according to which most speakers of English are non-native speakers (henceforth NNSEs), and all English varieties, native or non-native, are accepted in their own right rather than evaluated against a NSE benchmark." (ibid., p. 283-284, emphasis in the original).

Also according to Jenkins, Cogo and Dewey (2011), when non-natives speak differently from inner circle native varieties, rather than seeing this as deviations from the norm or lack of proficiency within an EFL perspective, we should understand these language practices as creative and fluid, which represent the potential or emerging characteristics of ELF. The notion of EFL, for example, follows theories that study such 
productions as mere first language interference, while ELF analyzes these same issues taking into account evolution and contact between languages.

Within an EFL perspective, inner circle native varieties are prioritized most of the time, and students are seen as speakers who learn a language that is not part of their daily lives. ELF, on the contrary, takes the focus away from the variety of English and the learning context and places it on the role that the language plays in a given context. Henceforth, according to Friedrich and Matsuda (2010, p. 22),

$[\mathrm{u}] \operatorname{sing}$ a framework that conceptualizes ELF as a function, rather than a linguistic variety, captures the dynamic nature of situation-based linguistic choices, recognizes the importance of nonlinguistic factors (e.g., use of strategies) in communication, and allows us to study the ELF phenomena multidimensionally and holistically. (FRIEDRICH; MATSUDA, 2010, p. 22).

In this sense, in situations where we use English as a foreign language - i.e., to communicate with native speakers and/or in contexts where English is the official language - we are operating only one of the many functions that the language can perform. Furthermore, by adopting an ELF perspective, we recognize a phenomenon of "increasing ownership, power, and responsibility that NNSs have in defining what is appropriate in the use of English in international contexts." (FRIEDRICH; MATSUDA, 2010, p. 25). Jordão, when discussing the opposition between EFL and ELF, also seems to agree with this point of view. The author states that:

the term ELF has been the preferred term (to the detriment of the EFL), as it refers to discussions about the uses, functions and contexts of learning English in the international scenario, taking into account the need to modify the power relations between the owners of the English language (its "native" speakers) and its users from several countries other than those in which this language is used as the first language. (JORDÃO, 2014, p. 19, emphasis in the original²).

To summarize, we return to some of the constituent characteristics pointed out by Canagarajah (2007). Conceiving English as a lingua franca entails to:

\footnotetext{
${ }^{2}$ In the original: "o termo ILF tem sido o termo preferencial (em detrimento do ILE), por remeter às discussões sobre os usos, funções e contextos de aprendizagem do inglês no cenário internacional, levando em conta a necessidade de modificar as relações de poder entre os donos da língua inglesa (seus falantes "nativos") e os seus usuários de vários países que não aqueles em que esta língua é usada como primeira língua.” (JORDÃO, 2014, p. 19).
}

Revista X, v. 16, n. 2, p. 409-436, 2021. 
(a) consider meaning as negotiated and intersubjective; (b) treat form as shaped by participants for their own purposes in each communicative activity; (c) affirm learners as capable of exerting their agency to renegotiate and overcome errors; (d) integrate learning and use; (e) provide for non-learner social identities in acquisition; (f) accommodate both purposive everyday communication and nonfunctional play as equally contributing to acquisition; ( $\mathrm{g}$ ) relate to language as practice; (h) treat cognition as situated and competence as performance; and (i) interpret the communication of novices in context without comparing it with NS norms or a target proficiency, or treating it as an interlanguage. (CANAGARAJAH, 2007, p. 930).

Furthermore, the field of ELF has developed over the years and changes in perspective were categorized into three phases by Jenkins (2015). During the first phase, studies on ELF focused on describing and codifying different non-native varieties; during phase two, scholars came to realize that variability was a central and defining characteristic of ELF communication, changing the focus to the functions of English across different Lingua Franca scenarios; the third phase aims at shifting the focus of ELF studies to practices more informed by the increasingly multilingual and complex nature of communication (JENKINS, 2015). Thus, the author proposes that instead of treating ELF as a variety among several others, we should talk about "repertoires".

It is important, therefore, to stress one point: ELF should not be conceived as a variety of English that can be described. If we consider recent studies on translingual practices, for instance, the notion of separated varieties has already been questioned. These research work with the concept of individual repertoires, which are complex and individual. Each person has their own repertoire, and uses different resources from it according to what they consider relevant and necessary at the moment. Rather than switching between two codes (languages), as exemplified by the notion of code-switching, subjects make use of the resources they have to make communication possible. According to García and Wei $(2014$, p. 80) " $[\mathrm{t}]$ ranslanguaging goes beyond having to acquire and learn new language structures, rather it develops the integration of new language practices into one linguistic repertoire that is available for the speaker to be, know and do [...]".

In addition, these repertoires are not fixed entities. Speakers bring their own repertoires to a communicative situation, and these repertoires were built throughout their lives, from different experiences, making them unique. However, their repertoires are also changing and adapting. They change in the interaction between different speakers, before, during and after communication happens. This is why, according to Jenkins (2015): 
The term repertoires in flux also emphasises more clearly that what ELF users already have in their linguistic repertoires and shared multilingual resources is only one part of their 'mobile resources', to use Blommaert's (2010) term, and that these may be added to or changed either temporarily or permanently during the course of the interaction." (JENKINS, 2015, p. 76, emphasis added).

Moreover, Duboc (2019) and Duboc and Siqueira (2020) argue that the way of understanding and working with the concept of ELF in Brazil is different than it is in other places. According to them, the Brazilian research goes beyond the three phases described by Jenkins (2015) because "our ELF studies have departed from the premise of monolingualism as a myth, followed by an urgent need for disinventing the so-called "named languages" (DUBOC; SIQUEIRA, 2020, p. 313). This is why they have coined the term "ELF feito no Brasil".

Given the particularities of ELF feito no Brasil, the authors believe that we should think about this language conception through the lens of decolonial studies. Thus, in order to join this task we have to ask ourselves questions such as " $[\mathrm{t}] \mathrm{o}$ what extent are global south ELF researchers engaged in disobeying, disrupting, and transforming the status of ELF research and practice?'(DUBOC; SIQUEIRA, 2020, p. 308). This movement promotes a "theoretical rupture with long-established ontological and epistemological assumptions" that must be "followed by an urgent call for action as current ELF research scope and range seem to be stretching far beyond mainstream European boundaries." (DUBOC; SIQUEIRA, 2020, p. 308). In summary, to engage with ELF feito no Brasil is to act locally:

Local action. Here is the greatest tenet of decoloniality which aims at going beyond the rhetoric and defeating the supposedly inefficiency in a type of academic research that still keeps itself comfortably cloistered in strictly discursive, theory-based discussions. This is exactly from where we wish to depart in the exercise of thinking and doing ELF research otherwise. (DUBOC; SIQUEIRA, 2020, p. 304).

Therefore, the ELF perspective is quite liberating and, at the same time, challenging. It meets with other discussions such as the myth of the native speaker as the one who, single-handedly, has power over English. In addition, this concept is comprehensive in its concern for accommodating different functions and relationships between the language and its non-native speakers living in different contexts. In this paper, we argue that ELF should take the center stage of English learning-teaching discussions. 


\section{CONSIDERING ELF AND THE CLASSROOM}

Reflecting on the concepts and issues problematized within the ELF paradigm requires us to review our teaching and learning practices. According to Canagarajah (2007), "[a]s we consider acquisition as transcending the control of the individual and the scope of interpersonal relationships, we have to explore one's language development in relation to that of a whole community of speakers." (CANAGARAJAH, 2007, p. 930). Jenkins, Cogo and Dewey (2011) indicate that the pedagogical implications of ELF include, among others, research on the configuration of different English language teaching programs, on the elaboration and analysis of teaching materials, approaches and methods, evaluation, and teacher education. The authors, therefore, defend the importance of investigating the pedagogical implications of ELF in the classroom. This investigation, in turn, should be "carried out not by academics but by language teachers themselves in order to reassess practices in their own specific, situated teaching contexts, and incorporate changes in approach in whatever ways and to whatever extent is most appropriate." (JENKINS; COGO; DEWEY, 2011, p. 306).

Authors like Siqueira (2014) point out that "a good part of this information and findings has not reached the common English language teacher around the world." (SIQUEIRA, 2014, p. 433). In this sense, Dewey (2014) affirms that, "[t]eachers regularly complain that when they have opportunity to read about and discuss theories and approaches to teaching, this is on a university campus, that is, when they are separated from their particular teaching context and removed from day-to-day classroom realities." (DEWEY, 2014, p 23). Thus, one can say that this knowledge production may not result in significant and perceptible changes when it comes to English teaching.

This perception is probably due to the fact that English language teaching was and still is - founded upon EFL concepts:

Initially, in English Language Teaching (ELT) not only was there the need to establish a stable basis for both learners and teachers, but this also brought about the demand for more efficient and suitable teaching materials. As a result, these publications have had a great impact on the proliferation of a specific view of the English language and culture, having contributed to an embedded understanding of what ELT should

\footnotetext{
${ }^{3}$ In the original: "boa parte dessas informações e achados não tem chegado ao professor comum de língua inglesa ao redor do mundo. O que tem ocorrido até o momento, em muitos contextos, quando o conhecimento sai da esfera acadêmica e chega à escola, por exemplo, é uma tomada de consciência no tocante à existência de diferentes ingleses e o valor de tal condição." (SIQUEIRA, 2014, p. 43)
}

Revista X, v. 16, n. 2, p. 409-436, 2021. 
be, not only on the part of teachers, but also of learners, parents, materials developers, policy makers, among others. (SIFAKIS et al., 2018, p. 185).

We work in schools that build their courses around textbooks that promote an EFL notion of language. Teachers have to introduce standard linguistic forms, following a sequence of contents that is supposed to have an increasing level of complexity and evaluate students' capability of simply reproducing them. This creates the expectations not only for students but also for teachers, who believe they should aim at speaking like inner circle native speakers. Thus, most of the time teachers do not see an opening to promote the changes in their places of action.

Due to the scenario presented above, Sifakis et al. (2018) examine the discussions held during the colloquium "ELF-awareness in ELT: bringing together theory and practice" on the impacts of ELF studies on English language teaching, which was part of the "ELF and Changing English: 10th Anniversary Conference of English as a Lingua Franca". Based on their studies about textbook materials and experiences with teacher training programs, the authors argue that we should try to integrate ELF discussions to our EFL-centered teaching contexts. According to the authors, current research must be focused on "(a) developing a comprehensive model for linking, in whatever way, the ELF construct with the ELT domain, and (b) describing good practices that demonstrate this very link." (SIFAKIS et al., 2018, p. 156).

Relating these issues to the Brazilian context, Duboc (2018) proposes connections between an ELF pedagogical perspective and concepts from postmodern studies. By doing so, the author addresses her own experiences with teacher education, emphasizing that we need to change our attitudes inside the classroom. Thus, one way of putting this into practice would be through smaller actions made locally by teachers when using the "gaps" or "cracks" of the curriculum:

[i]nstead of paradigmatic changes, when thinking of the challenge to move towards a "postmodern curriculum" founded on ELF principles, I tend to prefer small-scale, localized actions in my Teacher Education context - the curricular attitude between the gaps, so to speak - by which teacher educators and student teachers would find some fruitful room for problematizing and deconstructing knowledges and practices. (DUBOC, 2018, p. 183).

The author believes that this movement gives a chance for her students to reflect on their teaching practices and the ELF perspective while putting their own thoughts into question: 
The gaps or cracks within such curriculum are those very fruitful moments in which my student teachers have the chance to weaken their (pre)conceptions, values, and perspectives regarding issues such as language, culture, knowledge, nativeness, among others as precondition for their exercise of (self) interruption. (DUBOC, 2018, p. 177-178).

These moments, according to Duboc (2018), may be conducted through reading assignments, input sessions, debates, and others, and are also an opportunity for students to deconstruct stereotyped notions about communication in English. Even the concepts of ELF or EFL may be questioned, opening space for students to understand "the imminence of unresolved conflicts in certain communicative situations" (DUBOC, 2018, p. 178) and to think critically about their role as educators.

In the same line of thought, Jordão and Marques (2018) propose the combination of ELF and Critical Literacy (CL). The authors raise points of contact between ELF and CL mainly regarding meaning-making processes as a continuous and dialogic process. Thus, they explain that "[i]n a CL perspective, we interpret reality from our individual and collective experiences in negotiation with the context where and around which meaningmaking takes place." (JORDÃO; MARQUES, 2018, p. 63).

Therefore, Jordão and Marques highlight that constructing meaning is something that happens in a communication context and is not previously defined. This brings into question the process of negotiating meanings during a communicative situation, and deconstructs the idea that language teaching should be guided by the internalization of fixed pre-communication codes and structures. Thus, “[...] meaning is constructed as students and teachers interact with English in their communicative opportunities, both inside and outside school. In other words, language happens as students and teachers make use of it, in the actual language practices people are involved in." (JORDÃO; MARQUES, 2018, p. 63).

This highlights the importance of knowing and understanding students' individual repertoires, and how they are constantly being constructed in communication situations. For Jordão and Marques (2018), from the perspective of CL, meanings are constructed in the discourse and "cannot pre-exist the discourse clashes that happen in teachinglearning environments" since "the only way communication might successfully occur is through the negotiation of diverse repertoires that are brought into action in every single interaction" (JORDÃO; MARQUES, 2018, p. 65).

Galor and Haus (2019), as a more practical example, proposed classroom activities that promote critical reflection by students about concepts related to ELF and the power relations that are established during interactions through the English language. Revista X, v. 16, n. 2, p. 409-436, 2021. 
The authors conducted three activities with students from a language center, in which the learners had to reflect about power relations regarding English, the meaning of learning English today and what forms of English are valued (or not).

Thus, we propose this study with the impetus of also presenting a pedagogical experience informed by the concepts discussed so far. Our idea was to explore the repertoires that students bring to the English language classroom through autobiographical illustrations. In the following section we will describe the methodological steps of the study: first we will present what we understand as the visual method and how it was developed in this research; then we will explain how the analysis was conducted.

\section{METHODOLOGY}

As previously mentioned, this study is based on Melo-Pfeifer and Schmidt (2014). Their research deals with the development of the plurilingual competence of Portuguesespeaking immigrant children who live in Germany, with focus on the role of the heritage language in this process. The authors, with drawings obtained through the project "Imagens do (Ensino) Português na Alemanha", discuss the composition of plurilingual repertories and the self-image as plurilingual subjects of children between 6 and 12. Therefore, in a study involving 34 teachers, Melo-Pfeifer and Schmidt asked Portuguese descendant children, during extra curricular hours, to produce a drawing based on the instruction "draw yourself speaking the languages you know".

The authors also present two understandings of the concept of image, which we have adopted in this study: (i) as a "theoretical concept of reference capable of diagnosing, explaining and predicting the relationship of subjects with a given object"; and (ii) as a "data collection methodology (production of drawings)" (MELO-PFEIFER; SCHMIDT, 2014, p. 9, our translation ${ }^{4}$, emphasis in the original). In this sense, it is possible to state that, through the iconic representation (methodology) of the linguistic biographies of these learners, the authors were able to discuss the (re)constructions of the relationships between subjects and languages, as well as their learning experiences (theoretical concept of reference).

The authors also state that the use of drawings was very effective because the subjects were children at the beginning of schooling, with literacy levels still

\footnotetext{
${ }^{4}$ In the original: "conceito teórico de referência capaz de diagnosticar, explicar e prever o relacionamento dos sujeitos com determinado objeto"; e (ii) como uma "metodologia de recolha de dados (produção de desenhos)" (MELO-PFEIFER; SCHMIDT, 2014, p. 9, emphasis in the original).
}

Revista X, v. 16, n. 2, p. 409-436, 2021. 
underdeveloped. Moreover, based on an ELF perspective, it is very important to use a means of research and production of empirical material that allows the participation of students from different backgrounds and at different stages of learning, as well a method that encourages these students to use their creativity to report their experiences.

As Melo-Pfeifer and Simões state, the use of drawing in class is also "an instrument that allows students who cannot express themselves clearly through writing to have the opportunity to show what each language represents to them." (2014, p. 04). Therefore, in this study we asked students to look back at their past experiences and draw how they have learned English.

Although we worked with drawings, we also used the concept of narrative research, which, according to Pinho (2017, p. $228^{5}$ ), "can be defined as a process that allows the study and understanding of an experience through 'storytelling' or narrative writing.". The author also uses the notion of autobiography as "the writing of your own life" and as a model in which "the construction of meaning is exclusively made by the individual who narrates" (PINHO, 2017, p. 229).

Thus, we understand the drawings in our study as autobiographical narratives because they were produced by the students. They drew narratives of different moments and experiences they have lived, for example, when they illustrated experiences such as work meetings and exchange programs. In addition, considering that a narrative does not need to be chronological, we may examine these drawings as non-chronological narratives of a student's life.

Regarding the models used to analyze these narratives, we follow the concept of visual narrative analysis explained by Pinho (2017) based on the work of Riessman (2008). The method is "centered on multimodal texts, which integrate words and images, such as drawings, photographs, collages, videos..." (PINHO, 2017, p. 230, our translation ${ }^{6}$ ). Moreover, regarding the analysis of data collected through multimodal texts, the author states that it is necessary to consider "(a) the context/history of the image's production, (b) the image itself, and (c) how it can be interpreted" (PINHO, 2017, p. 230, our translation").

\footnotetext{
${ }^{5}$ In the original: "A investigação narrativa pode definir-se como um processo através do qual se estuda e compreende a experiência através do 'contar de histórias' ou da escrita narrativa." (PINHO, 2017, p. 228).

${ }^{6}$ In the original: "(iv) análise narrativa visual, integrando abordagens centradas em textos multimodais, que integram palavras e imagens, tais como desenhos, fotografias, colagens, vídeos..." (PINHO, 2017, p. 230).

${ }^{7}$ In the original: “... Neste caso, trata-se de analisar como as identidades são compostas e representadas visualmente, sendo, na opinião da autora, importante ter em conta (a) a história de produção da imagem, (b) a própria imagem e (c) como esta pode ser interpretada." (PINHO, 2017, p. 230).
} 
Thus, in our study we analyzed the drawings based on the context of production, the images and symbols present in the data and proposed possible interpretations.

The empirical material presented in this article was produced in an activity conducted with two Intermediate $3^{8}$ level groups of the English course of the Center for Languages and Interculturality (Celin) of the Federal University of Paraná (UFPR). The task was conducted during the first day of classes with both groups and was designed so that students could also use this moment to introduce themselves and to get to know their colleagues. 14 students from Group 1 and 8 students from Group 2 participated in the activity.

A questionnaire was sent to students weeks after the activity. The objective of this survey was to assess the students' profiles, establish connections between them when possible and to gather information that could be helpful during the analysis of the drawings. As the data will be addressed together and the division of the two groups would be irrelevant for the results, we synthesized the answers in one. The students' ages varied from 18 to 47 years. Regarding educational background, 55\% of the participants were undergraduate students, $30 \%$ had graduate or specialization degrees, $10 \%$ had undergraduate degrees, and 5\% were graduates or were taking specialization courses.

The questionnaire also sought to obtain information on the areas of study and activities performed by students, for which we gathered varied answers. The students who answered the questionnaire were from the following areas: computer science, design (fashion, marketing, and communication), law, nursing, engineering (environmental, mechanical, and electrical), pharmacy, medicine, neurophysiology, mathematics, nutrition, and information technology. Finally, we asked students about their experiences with formal English learning previous to Celin, to check if they had had contact with other English schools. Half of the students declared they had and the other had not. In addition, when asked about the first level they took at Celin ${ }^{9}$, the answers again were quite varied, with students that had taken the course from the first level (Basic 1) and those who had jumped straight to the last level (Intermediate 3 ).

Thus, one can see that the students' profiles were very heterogeneous. Although all participants in the research had already had some contact with the academic environment, the majority of them study or work with different areas of knowledge and have had different experiences with English learning.

\footnotetext{
${ }^{8}$ This is the last and highest level of Celin's regular English course.

${ }^{9}$ During the registration period, students can take a placement test that posits them in the courses according to their previous experiences and their knowledge of English.
}

Revista X, v. 16, n. 2, p. 409-436, 2021. 


\section{The activity and selection of drawings}

First, we told students that they would do an activity different from the ones they were used to in a first class of an English course: they would have to draw. We told them that they might need to get out of their routine - since, except for a few, most of them did not perform tasks like this in their daily lives - but that they would not be evaluated by the drawings and should not worry about it. We made these warnings because we believed that some students might not be comfortable with the activity. However, this was not the case and everyone engaged and participated in all stages.

We divided the students into three groups and handed a blank sheet to each one. We wrote "How did I learn English?" on the board and asked students to think about the phrase and, if they wanted, they could discuss it with their colleagues. Then, students should draw the experiences they have had with English learning. During the activity, we passed by the groups and talked to them, asking about the drawings and their meanings. At times, students told us things that were not on the sheet of paper, and then we encouraged them to add that to the drawing.

When everyone had finished the activity, we asked them to present their drawings orally to the class, explaining their life trajectory and their experiences with English. This moment was interesting because the students explained their productions to their classmates, and those who could not express everything they would like to in their drawings, did so orally. Finally, when everyone had already presented, we asked them to reflect on common aspects among the drawings. We also drew attention to the fact that they are responsible for much of their learning and to the fact that they learn in many different ways.

Thus, we synthesize these discussions together with the analysis of the drawings in the next section. It is important to emphasize that the objective of the activity was not only the production of empirical material for this research, but also to open the classroom for reflections made by the teacher and students together.

After the activity was conducted with both groups, we scanned students' productions. Then, we conducted a partial analysis of all drawings, listing the elements present in each of the illustrations. Based on this list, we developed some categories in order to outline and describe the elements that appeared in the drawings (Table 1). Finally, we selected some of the illustrations to be discussed in the next section. We chose to discuss the drawings that better summarized the findings listed below. 
Table 1: General description of the drawings.

\begin{tabular}{|c|c|c|}
\hline Category & Elements considered & Appearances \\
\hline Music/Podcasts & $\begin{array}{c}\text { Musical notes, headphones, music devices, } \\
\text { singers, the word "music", CDs }\end{array}$ & 19 \\
\hline Series/movies & $\begin{array}{c}\text { Netflix (symbol/word), the word "movie", TV, } \\
\text { computer, cell phone }\end{array}$ & 17 \\
\hline Reading/Study & $\begin{array}{c}\text { The word "reading", articles, dictionaries, laptop } \\
\text { to study, activities, books }\end{array}$ & 11 \\
\hline Formal education & $\begin{array}{c}\text { Teacher, students, classes, schools (regular and } \\
\text { language center), textbooks, activities }\end{array}$ & 7 \\
\hline Videos/Games & $\begin{array}{c}\text { YouTube (symbol/word), computer, cellphone, } \\
\text { video games, game controllers }\end{array}$ & 5 \\
\hline Communication & $\begin{array}{c}\text { People talking, messages, work meetings with } \\
\text { Brazilian and/or foreign speakers }\end{array}$ & 2 \\
\hline Connections & $\begin{array}{c}\text { Arrows and Plus Signs interconnecting different } \\
\text { elements }\end{array}$ & 11 \\
\hline $\begin{array}{c}\text { Travel/exchange } \\
\text { programs }\end{array}$ & Airplane, country symbols, foreigners, flags & 20 \\
\hline
\end{tabular}

Source: The authors (2020).

\section{RESULTS AND DISCUSSION}

\section{Drawing 01:}

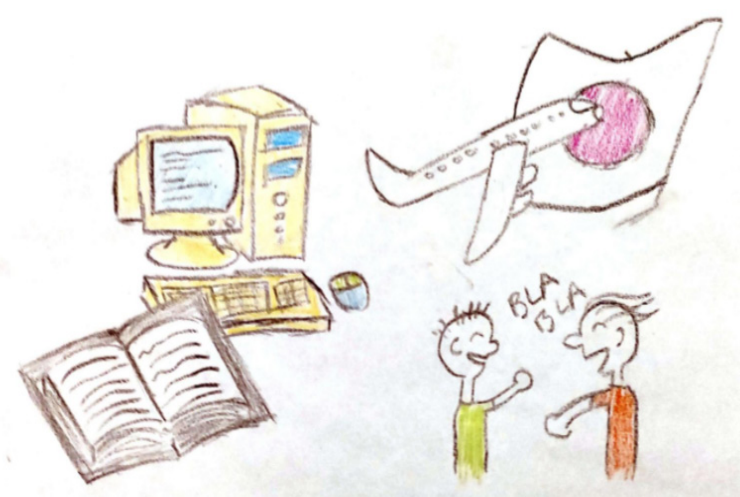

Source: The authors (2020). 
\#PraCegoVer: Colorful drawing. On the left side, there is a computer with CPU, a keyboard and a book. On the right side, there is an airplane over the Japanese flag. Below the airplane, there are two people talking.

On the left of Drawing 01 we see the image of a computer and a book in front of it. According to the student that drew it, the intention was to represent his background in Computer Science, since many of the books, programs and other materials related to the course are in English. On the right side of the drawing there is a plane, together with the Japanese flag, and two people communicating below, which represent the student's experience in an exchange program. According to him, the classes were taught in English in Japan, and this was the language used to communicate with teachers and colleagues.

\section{Drawing 02:}

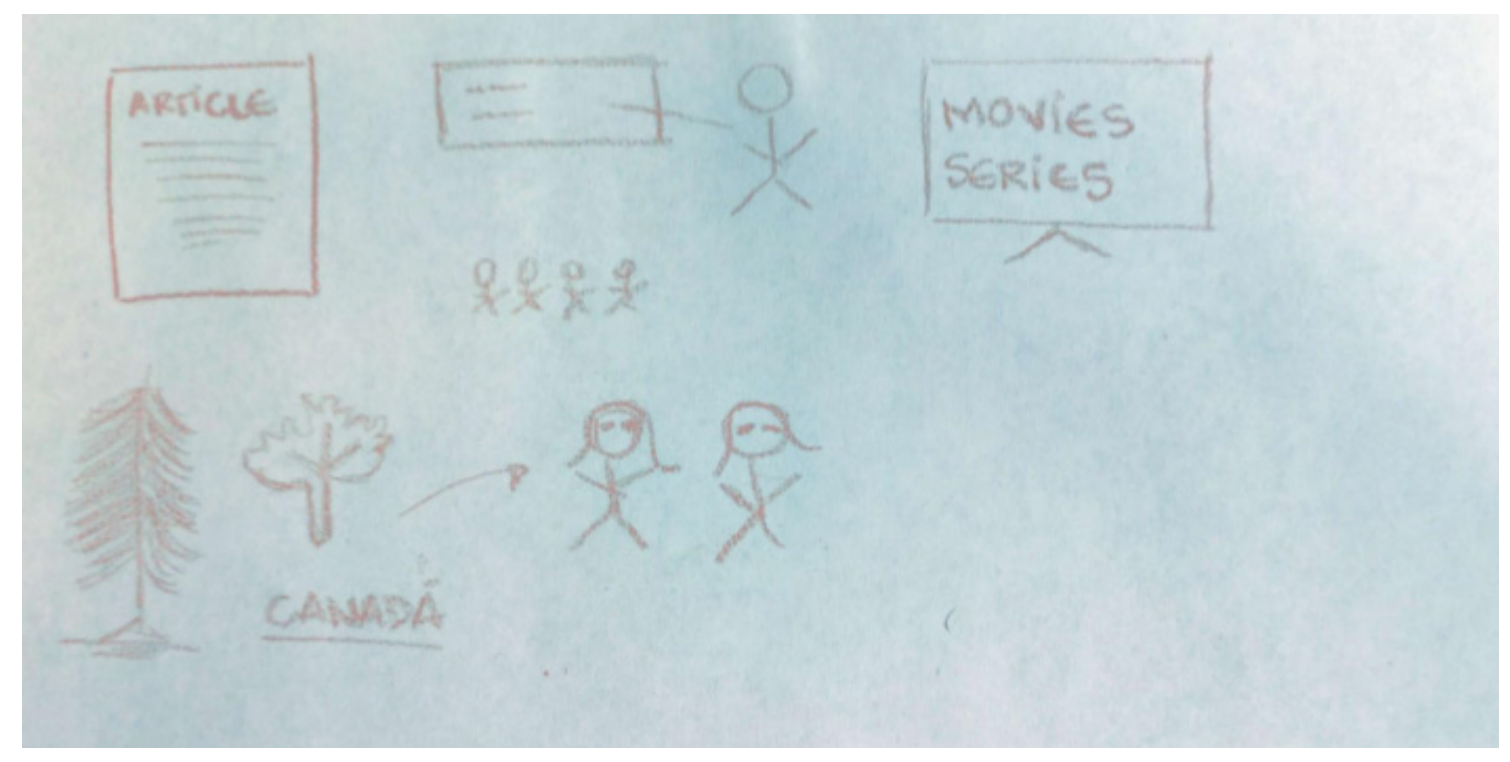

Source: The authors (2020).

\#PraCegoVer: Orange drawing. In the upper part, from left to right, there is an article, a classroom with a blackboard, a teacher and some students, and a TV with the words movies series. At the bottom, there is a tree, a leaf, the word Canada and an arrow indicating two people.

Drawing 02 is similar to the previous one. Under the command "How did I learn English?", the author points out three elements as the main representatives of her learning: on the right, there is a drawing of a screen and the words "movies" and "series", which show that this student considers entertainment as important for her learning; in the center, there is a drawing of a teacher in front of a board. Next to him, there are 
students, represented in the same way - but smaller - than the teacher; finally, there is the representation of an article on the left, which, as in Drawing 01, symbolizes the academic trajectory of the student. Below, we see "Canadá" (written in Portuguese), a tree and the maple leaf, emblematic symbols for that country. Right next to it, there are two people communicating. According to the student, she tried to represent Asian features in her drawing, since she used English to communicate with her exchange colleagues who were mostly Japanese.

In both Drawings 01 and 02, the academic career and the experience abroad stand out in the English learning experiences of these speakers. It is interesting, however, that both students signal these exchange experiences highlighting the communication with non-native English speakers - the former, for example, has been to a country that does not have English as its official language ${ }^{10}$. This shows that, for these students, we can presume that English is playing the role of a lingua franca. The focus of their learning is communication, so the negotiations necessary for this to happen are extremely important and they do not depend on the variety of English used by native speakers. If we base ourselves on the definition proposed by Friedrich and Matsuda (2010), we can affirm that this is a case of using English as an international lingua franca, since one of its characteristics is its use during communication between groups of different nationalities.

In the sequence, we can see that in Drawings 03 and 04, students depict a situation that is partially similar to those previously presented: both point out that work meetings are important elements of their learning. In Drawing 03, the student also described the individuals present at these meetings: the boss, the CEO, and the Polish and Arabic suppliers. In Drawing 04, the student depicts a work meeting with three people: one of them is in front of a board with graphics and texts speaking to the other two. However, she does not specify who these individuals are and what are their nationalities.

\footnotetext{
${ }^{10}$ We understand that the English language has an essential role in the academy, which explains some issues discussed here. However, the point we are trying to raise is the fact that English, in this context, is not tied to a native variety of teaching and learning, but rather performs an international communication function.
} 


\section{Drawing 03:}

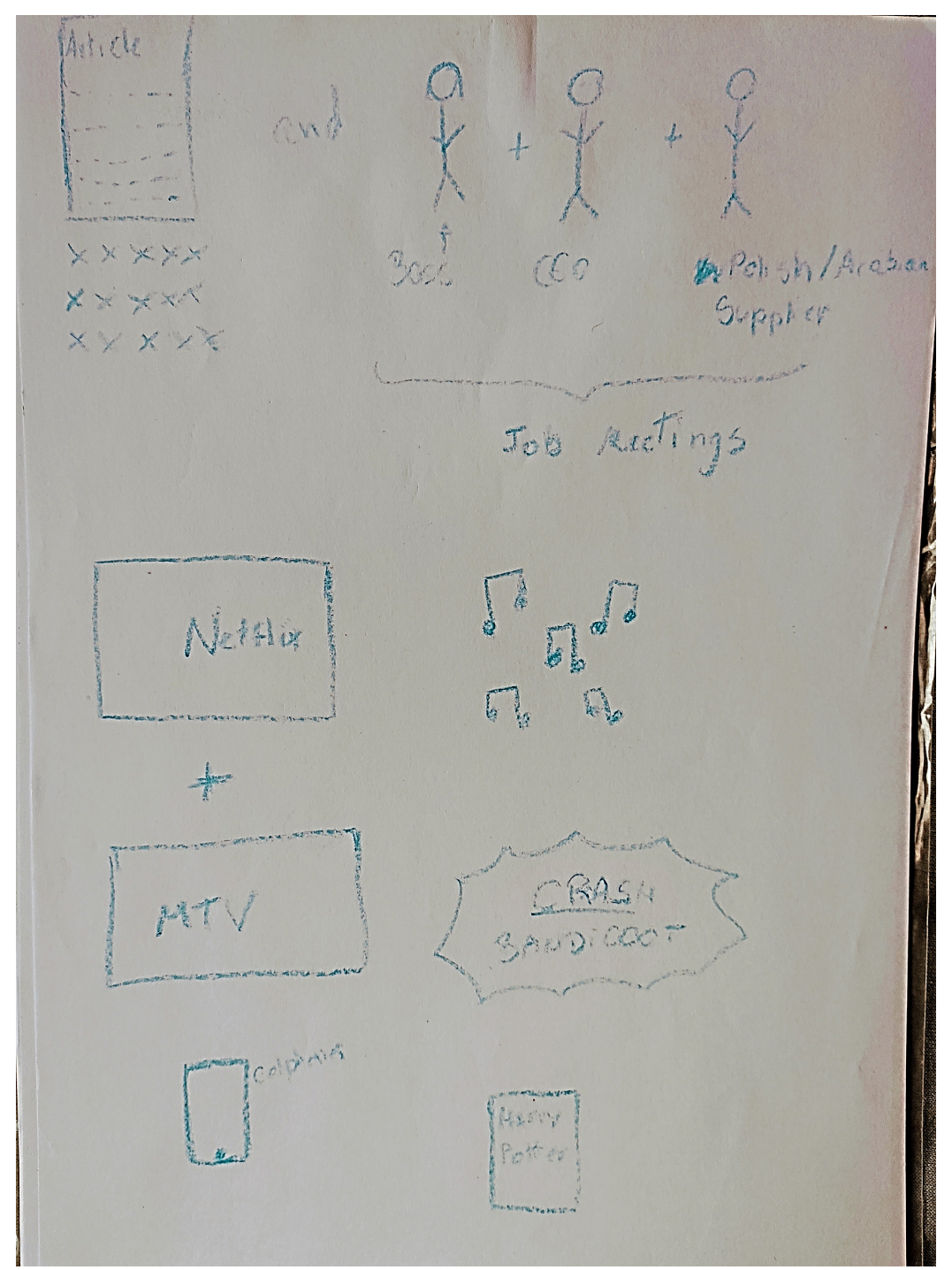

Source: The authors (2020).

\#PraCegoVer: Blue drawing. In the upper part from left to right, there is a sheet of paper with the word article, three people, and the words boss, ceo, Polish/Arabian/supplier joined by a bracket that indicates the expression job meetings below. Under these drawings, on the left side, there is a TV with the word Netflix, another TV with the word MTV, and below there is a cell phone. On the right, there are side musical notes, the word crash bandicoot and a book with the title Harry Potter. 


\section{Drawing 04:}

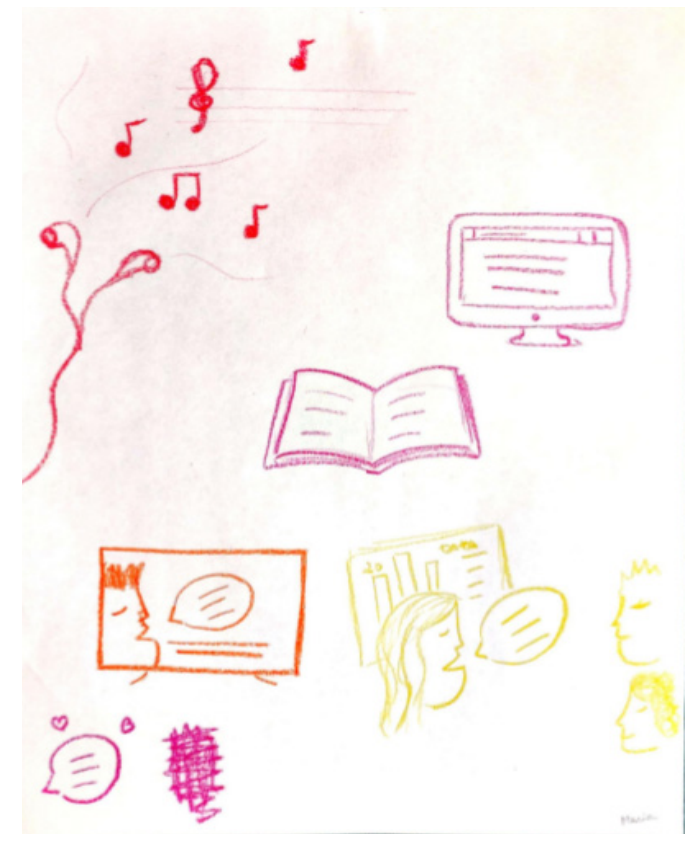

Source: The authors (2020).

\#PraCegoVer: Colorful drawing. At the top left, there are several musical notes, on the right, there is a computer monitor. A little below, in the center, there is an open book. Below, on the left side, there is a TV with the image of a person speaking. Next to it, there is a board with a graphic and a person speaking to two others in front of it. At the bottom, there is a speech bubble with two hearts around it and some sketches.

What both Drawings 03 and 04 have in common is the fact that, even working in Brazilian territory, English is part of these students' daily lives and professional careers. In the first case, the student uses English to meet with suppliers of other nationalities, and in the second, the student shows that she meets with her Brazilian coworkers (she clarified this when presenting her production to the class). To different degrees, both students have to deal with linguistic and cultural differences. They have had different experiences regarding language learning, resulting in different repertoires, which lead them to creatively use whatever resources needed for communication to be effective.

Other elements that also appear in these drawings - and in Drawing 02 as well - are entertainment content and electronic devices. In Drawing 03, for example, there are two screens in which we notice references to the Netflix streaming service and to the North American channel MTV. Next to it, there are musical notations and the name "Crash Bandicoot", referring to the main character of a famous series of electronic games of the same name. Below, there is the representation of a cell phone and a book entitled 
“Harry Potter". In Drawing 04, there are headphones and also musical notation. Next to it, there is the drawing of a computer and what appears to be a notebook or a book in front of it. As in the previous production, there is also a screen that seems to represent series and movies. Finally, in the bottom left corner we can identify a balloon with text and hearts, which can mean communication with other people through messages.

\section{Drawing 05:}

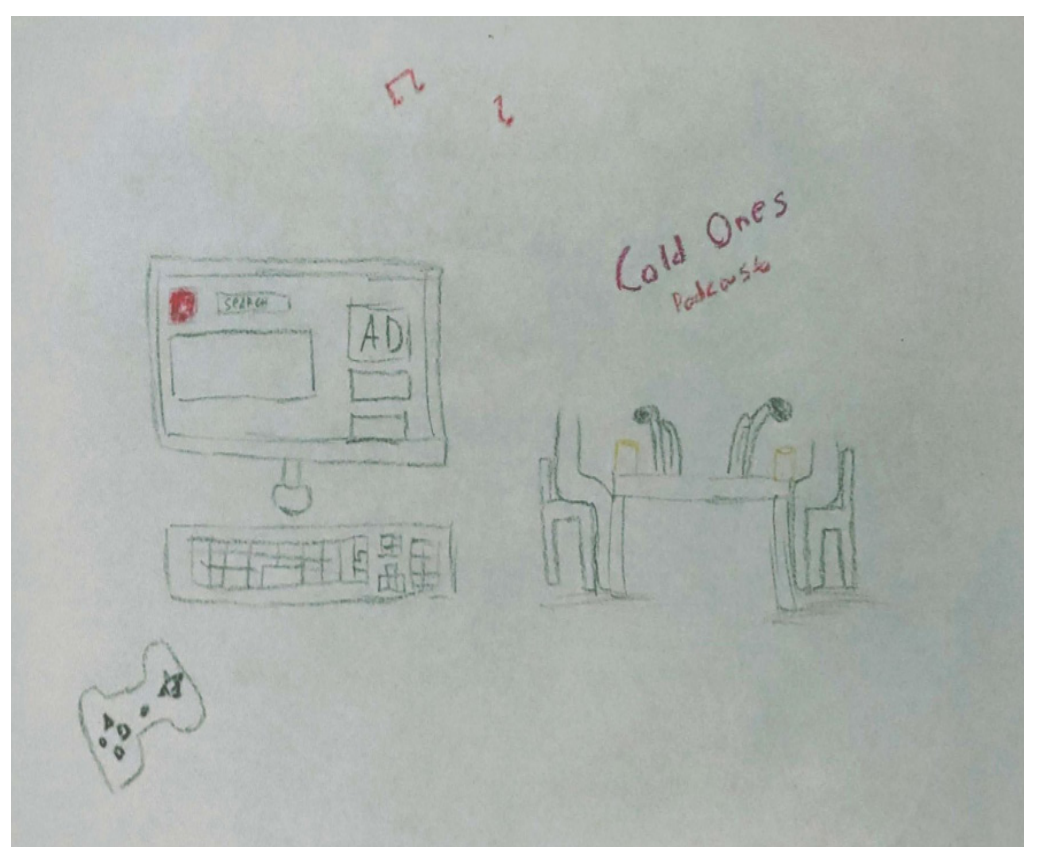

Source: The authors (2020).

\#PraCegoVer: Black drawing with red details. On the left, there is a computer monitor and a keyboard. Below, there is a game controller. On the monitor screen, there is some information in the form of rectangles. On the right side of the computer is written Cold Ones Podcasts and below there is the drawing of two people seated facing each other, focused from the shoulder down. Between them, there is a table and in front of each person there are mugs, microphones and cameras.

Drawing 05 presents elements very similar to those of the previous drawings, with the difference that this one mentions podcasts (the program "Cold Ones", clarified by the student during the oral presentation of the drawing). These images are very representative of the agency of students in their own experiences with English. Their knowledge is not limited to the experiences and materials covered in the classroom. On the contrary, the vast majority of students pointed out external elements as essential in their learning journey. These students do not need a textbook based on a native and standard variety of the English language. They learn by themselves through music, books, podcasts, and video games. 
Some students, such as the author of Drawing 05, also point out the contact with online courses as significant for their English learning. Moreover, these personal experiences are often added to activities developed at Celin, showing that these and other elements are in constant contact and connection (Drawing 06). However, students such as the author of Drawing 07, even when performing an activity conducted in a language course, do not put in their drawings any element that represents their formal education of English. This is recurrent in the productions: of the 22 drawings, half (11) do not present references to schools or English courses.

\section{Drawing 06:}

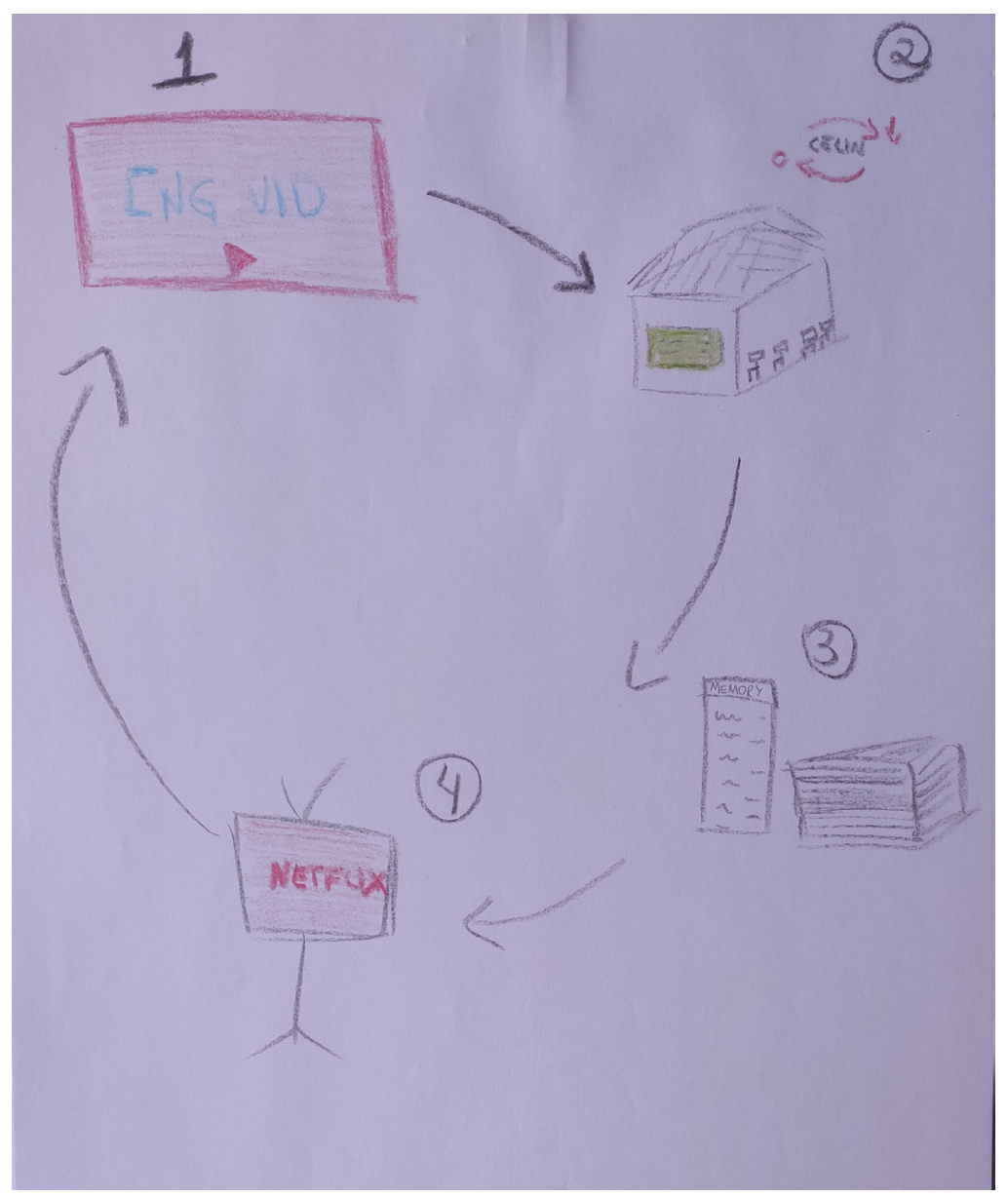

Source: The authors (2020).

\#PraCegoVer: Colorful drawing. Several images form a circle. Numbered from 1 to 4 clockwise, at 11 o'clock, 1, there is a TV with the word ENG VID and the play sign. An arrow indicates the drawing 2, at 2 o'clock, there is a school with a classroom and above it the logo of Celin. Another arrow indicates drawing 3, at 5 o'clock, two books, one with the title Memory. An arrow indicates drawing 4, at 7 o'clock, there is a TV with the word Netflix. 


\section{Drawing 07:}

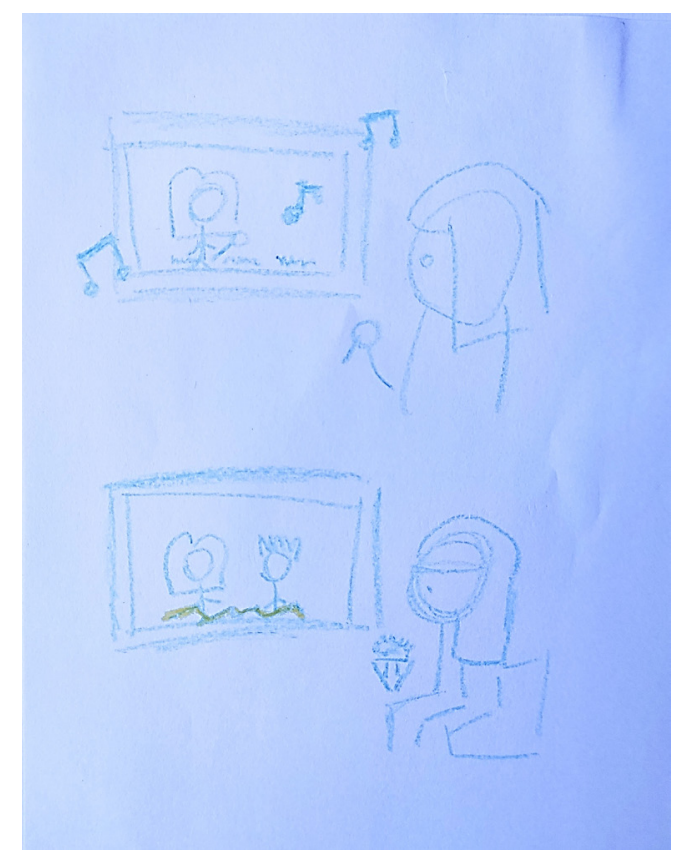

Source: The authors (2020).

\#PraCegoVer: Blue drawing. On the top, there is a TV with images and musical notes around it. In front of it there is a girl singing into a microphone. Below, there is a TV showing a couple, in front of a girl sitting watching.

In other words, self-taught experiences, which go beyond the classroom and involve real language contact elements and situations, seem to stand out among some students. In these drawings, students consciously exposed that elements present in their daily lives, often relevant to their identities - such as a videogame or a favorite book -, are important resources for their learning. Therefore, when students state that they learn English while watching their favorite series or playing the games they like, EFL is most likely not involved in this action.

In addition, the students' productions evidence how much individual creativity is relevant in their linguistic biographies. This shows the importance of activities that explore students' subjectivities and their different investments, which reflect on the resources they use in each situation. According to Jenkins, Cogo and Dewey (2011):

ELF speakers exhibit substantial linguistic variation in their interactions for a range of purposes, including the projection of cultural identity, the promotion of solidarity, the sharing of humour and so on, rather than (primarily) to promote intelligibility between speakers from different 
first language groups or as a result of interlocutors' different levels of proficiency. (JENKINS; COGO; DEWEY, 2011, p. 296).

As shown by the questionnaire answered by the students, their profiles are quite heterogeneous. A student that is learning English to participate in an exchange program may enjoy a certain kind of activity more, while the one who uses English for reading scientific articles may prefer another. In this sense, when we teach from an ELF perspective, we need to integrate these differences in the classroom and explore the different investments.

\section{POSSIBLE PATHS}

As mentioned before, one of the objectives of this study was to evaluate the extent to which the experiences of these students potentially differ from the traditional notion of English as a foreign language, and how they can be understood within an English as a Lingua Franca perspective. In addition, as language teachers we believe that providing moments of reflection on the teaching and learning process is extremely relevant. Through these moments, we can try to understand not only to what extent the discussions about the role of English today can impact - or not - the conceptions students bring into the classroom, but also how open they are to these issues and if they see themselves as agent speakers of English.

\section{Drawing 08:}

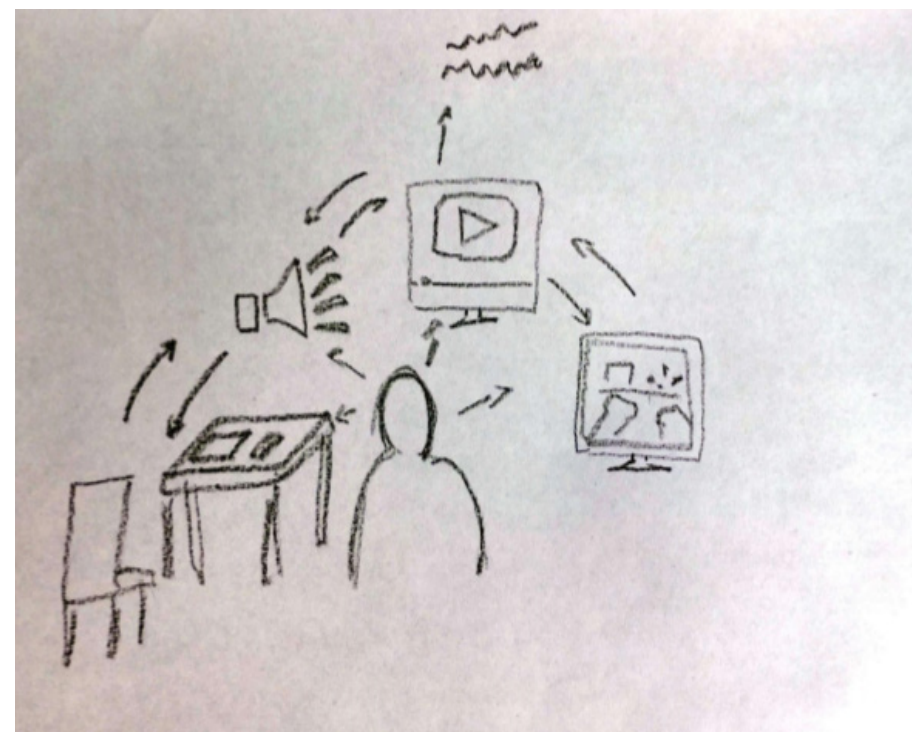

Source: The authors (2020). 
\#PraCegoVer: Black drawing. In the center, there is a person with four arrows around them that indicate several drawings, from left to right in a clockwise direction. At 9 o'clock, there is a table with some school supplies and a chair. At 11 o'clock, there is a speaker. At 1 o'clock, there is a computer screen with the play sign and, above, an arrow indicating two lines. At 3 o'clock, there is a monitor with several images. Between the drawings there are two arrows in a double direction.

Speakers such as the author of Drawing 08 - which summarizes the discussions held thus far - and the other drawings presented in the previous section show how the linguistic autobiographies and students' learning journeys are constituted in a unique way. In addition, the illustrations show how these students use English in their daily routines. From work meetings, contact with friends of other nationalities, studies, and even leisure, English is present in their lives in the most diverse situations. These situations are interconnected and make English no longer a language "of the other". Each non-native speaker is also an agent, capable of using English creatively and efficiently, establishing communication in the most diverse spheres, and shaping their subjectivity as English speakers.

We understand that the impact that this activity may have had on students' perceptions and how they understand the English language and their learning processes cannot be immediately measured. We are also aware of the fact that the activity was conducted in a language center connected to a federal university - which may be considered by some as a privileged research space - and that the results are certainly influenced by the students' profiles. However, this study leaves us optimistic when we remember that the activity lasted much longer than we expected. In the beginning, we believed that the students would not like to draw in an English class. But, on the contrary, everyone engaged not only in creating a representation and explaining their experiences with the language, but also in listening to their colleagues and establishing bridges between the different reports. We strongly believe, therefore, that the methodology used here can be adapted to different contexts.

It is important to finish this text highlighting the fact that we are English teachers reflecting about the implications of ELF upon pedagogical practices. Our intention was to, at first, show that although teaching English as a Foreign Language may still prevail in many teaching contexts, changing the perspective is possible because there is room to integrate ELF to the classroom - as supported by Sifakis et al. (2018). Thus, based on the discussion presented in this paper, we would like to propose three possible approaches that could help the development of an ELF-informed teaching.

Throughout the drawings, students identified music, videos, movies, TV shows, video games, and podcasts as part of their learning repertoire. Thus, we proposed that 
(i) practices involving multimodality can be perceived as a way to develop an ELF practice. This enables a pedagogical approach less centered on a textbook unaware of the specificities of certain contexts and opens the classroom for elements that are part of students' personal interests. Moreover, the multimodal work with language enables students to have contact with a greater range of texts and different contexts where they may use English, as well as with a greater presence of non-native speakers from the most diverse backgrounds.

Moments such as the drawing activity presented in this paper are also relevant for the development not only of an ELF-informed practice, but also to help students develop an ELF awareness. This is why we propose (ii) explicit reflections as one possible step towards this task. These can be done through activities that directly tackle issues regarding language and culture, such as the ones proposed by Galor and Haus (2019), where the syllabus of the course allowed the introduction of debates related to power relations and language in dialogue with the topics that were already being discussed in class.

Finally, to open up the center stage of the class by proposing (iii) spaces for students to share their repertoires so they can assume the position of teachers (i.e. flipped classroom moments) can give students the opportunity to see themselves as agents of the language. For example, one or more students can give a presentation about their exchange experience and what they have learned in another country; whereas others may teach the class something about their field of work/research; others can present a review about an interesting movie or TV show they recently watched, or talk about their hobbies and interests. In fact, there is a universe of possibilities to show students that they are legitimate English speakers and that they can also share their knowledge with other speakers through this language.

All in all, it is important to stress the fact that we do not see this as a recipe or a framework to be followed in order to achieve certain results. As we mentioned in the introduction, we do not believe that such an attempt is possible. We defend, however, that teachers should try to look at their practices and local contexts with critical lens. The ideas that we proposed in this article can be analyzed and approached in different and unique ways, considering the realities presented by each specific scenario. Thus, the methodology used in the study presented may help English teachers to understand the educational contexts in which they are involved and rethink their own teaching practices regarding ELF. Our aim now will be to employ these strategies in our classrooms in order to evaluate their potential in the search for an ELF-informed approach. 


\section{ACKNOWLEDGEMENTS}

We would like to thank our dear friend and colleague Natália Bittencourt Junghans for her help with the revision of our manuscript. We also thank the editors and reviewers for their insightful comments and suggestions during the publication process.

\section{REFERENCES}

CANAGARAJAH, S. Lingua Franca English, Multilingual Communities, and Language Acquisition. The Modern Language Journal. v. 91, p. 923-939, 2007.

DEWEY, M. Pedagogic Criticality and English as a Lingua Franca. Atlantis: Journal of the Spanish Association of the Anglo-American Studies. v. 36, n. 2, p. 11-30, 2014.

DUBOC, A. P. M. The ELF teacher education: Contributions from postmodern studies. In: GIMENEZ, T.; KADRI, M. S. El; CALVO, L. C. S. (Ed.). English as a Lingua Franca in Teacher Education - ABrazilian perspective. Berlin: De Gruyter Mouton, p. 159-187, 2018.

DUBOC, A. P.; SIQUEIRA, S. ELF feito no Brasil: expanding theoretical notions, reframing educational policies. Status Quaestionis, v. 2, n. 19, p. 297-321, 2020.

DUBOC, A. P. M. Falando francamente: uma leitura bakhtiniana do conceito de "inglês como língua franca" no componente curricular língua inglesa da BNCC. Revista da Anpoll, v. 1, n. 48, p. 10-22, 2019.

FRIEDRICH, P.; MATSUDA, A. When Five Words Are Not Enough: A Conceptual and Terminological Discussion of English as a Lingua Franca. International Multilingual Research Journal, v. 4, n. 1, p. 20-30, 2010.

GALOR, A. L.; HAUS, C. O ENSINO DE INGLÊS COMO LÍNGUA FRANCA: UM RELATO DE PRÁTICAS. PERcursos Linguísticos, v. 9, n. 22, p. 254-274, 2019.

GARCIA, O.; WEI, L. Translanguaging to learn. In: WEI, L.; GARCIA, O. Translanguaging: Language, Bilingualism and Education. Basingstoke: Palgrave Macmillan, p. 78-89, 2014.

JENKINS, J.; COGO, A.; DEWEY, M. Review of developments in research into English as a lingua franca. Language Teaching, v. 44, n. 3, p. 281-315, 2011.

JENKINS, J. Repositioning English and multilingualism in English as a Lingua Franca. Englishes in Practice, v.2, n. 3, p. 49-85, 2015. 
JORDÃO, C. M. ILA - ILF - ILE - ILG: Quem dá conta? In: RBLA, Belo Horizonte, v. 14, n. 1, p. 13-40, 2014.

JORDÃO, C. M.; MARQUES, A. N. English as a lingua franca and critical literacy in teacher education: Shaking off some "good old" habits. In: GIMENEZ, T.; KADRI, M. S. El; CALVO, L. C. S. (Ed.). English as a Lingua Franca in Teacher Education - A Brazilian perspective. Berlin: De Gruyter Mouton, p. 53-68, 2018.

MELO-PFEIFER, S. The multilingual turn in foreign language education: Facts and fallacies. In: BONNET, Andreas; SIEMUND, Peter (orgs). Foreign Language Education in Multilingual Classrooms. Hamburgo: John Benjamins, 2018.

MELO-PFEIFER, S.; SCHMIDT, A. "Desenha-te a falar as línguas que conheces": imagens de crianças luso(fono)descendentes na Alemanha acerca da sua Competência Plurilingue. In: ANDRADE, A. I.; ARAÚJO E SÁ, M. H.; et al. (orgs.), A diversidade linguística nos discursos e nas práticas de educação e formação. Aveiro: Universidade de Aveiro, p. 159-182, 2014.

PINHO, A. S. Narrativas (visuais) na formação de professores: olhares da investigação e formação. In: MELO-PFEIFER, S.; SIMÕES, A. R (orgs.). Plurilinguismo vivido, plurilinguismo desenhado: Estudos sobre a relação dos sujeitos com as línguas. Santarém: Instituto Politécnico de Santarém, p. 221-241, 2017.

SIFAKIS, N. C. et al. ELF-awareness in ELT: Bringing together theory and practice. Journal of English as a Lingua Franca, v. 7, n. 1, p. 155-209, 2018.

SIQUEIRA, D. S. P.; SOUZA, J. S. Inglês como Língua Franca e a esquizofrenia do professor. Estudos Linguísticos e Literários. n. 50, p. 31-64, 2014.

SIQUEIRA, D. S. P. English as a Lingua Franca And ELT Materials: Is the "Plastic World" Really Melting? In: BAYYURT, Y.; AKCAN, S. (Eds.).Current perspectives on pedagogy for English as a lingua franca. Berlin: De Gruyter, p. 239-257, 2015.

Recebido em: 12 out. 2020.

Aceito em: 19 jan. 2021. 